\title{
FAKTOR-FAKTOR YANG BERHUBUNGAN DENGAN PELAKSANAAN ASUHAN KEPERAWATAN DI RS GRANDMED TAHUN 2020
}

\section{JUNI MARIATI ${ }^{1}$, BETI SUSANTI ${ }^{2}$, DIAN ANGGRI YANTI ${ }^{3}$, SYATRIAWATI, ROSITA GINTING ${ }^{5}$,PRATIWI CHRISTA SIMARMATA ${ }^{6}$, PITRIANI}

\author{
1,2,3,4,5,6,7 INSTITUT KESEHATAN MEDISTRA LUBUK PAKAM \\ Jln. Sudirman No. 38 Kel. Lubuk Pakam Pekan Kec. Lubuk Pakam Kab. Deli \\ Serdang Provinsi. Sumatera Utara \\ e-mail: juni mariati31@yahoo.com
}

DOI $10.35451 / j k f . v 3 i 2.662$

\begin{abstract}
Nursing care services certainly cannot be separated from the nursing process, starting from nursing assessments, nursing diagnoses, nursing interventions, nursing implementation, evaluation and documentation. Implementation of the nursing care process is still a problem in nursing services. The problem found in the nursing process is the accuracy of nurses in applying the nursing care process. The aim of this study to analyze the accuracy of the implementation of the nursing care process. There are several factors related to step by step use of the caring and care at RS Grandmed Lubuk Pakam in 2020. This study used an analytical survey research with a cross sectional study approach. The population in this study were all employees of 3 Depan. The sample in this study was used as many as 12 respondents according to the inclusion criteria. The results that, there is no relationship between nurse education and the vocasi step by step use of the caring and care $(p=1)$, there is no relationship between the work tenure of nurses and step by step use of the caring and care ( $p=0.293$ ), workload of nurses and the vocasi of step by step use of the caring and care $(p=0.293) . p=0.010)$, incentives and of nursing care $(p=$ $0.010)$, work atmosphere and the vocasi step by step use of the caring and care $(p=0.045)$, So it can be workload, incentives, work atmosphere and leadership style on.
\end{abstract}

Keywords: Workload,work atmosphere and leadership style.

\section{PENDAhUlUAN}

Rumah Sakit mempunyai fungsi sebagai organisasi pelayanan kesehatan. Salah satunya adalah kita memberikanpelayanan keperawatan. Hal ini dibuktikan tenaga perawat mempunyai peranan penting dalam mewujudkan dan mendasari pada saat melaksanakan asuhan keperawatan dan berkesinambungan, hal ini merupakan salah satu kelebihan tersendri dibandingkan (kemenkesKes RI, 2018).

Pelayanan keperawatan yang sangat dibutuhkan oleh masyarakat dan saat ini sangat menjadi perhatian masyarakat luas. Perhatian mereka tidak saja pada aspek kuantitas, tetapi sekarang ini menyangkut aspek kualitas pelayanan kesehatan 
itu sendiri. Pelayanan kesehatan tersebut secara profesional yang diharapkan mampu memberikan pelayanan yang dibutuhkan oleh masyarakat kapan pun dan dimana pun. Tenaga kesehatan atau health professional tersebut misalnya tenaga keperawatan, kebidanan, kedokteran, kesehatan masyarakat, dan tenaga kesehatan lainnya. Salah satu topik yang masih hangat dibicarakan dan terus dikembangkan adalah tenaga keperawatan, salah satu bidang atau areanya adalah keperawatan kesehatan masyarakat atau keperawatan kesehatan komunitas (Swarjana, 2016).

Perawatan dan kepeduliaan yang signifikan terhadap pengembangan pelayanan kesehatan sehingga kualitas pelayanan kesehatan bergantung pada salah satu yang berkualitas (PPNI,2016).

Terdapat ketetapan yang ditetapkan Depkes RI tersebut, semua telah dicapai pelaksanaan asuhan-asuhan keperawatan pemerintah juga mengeluarkan ketetapan bernomor. 105/Yan.Med/Raw/1/1988, tentang bagaimana pelaksanaan sebenarnya di lapangan, Namun pada kenyataannya tidak sesuai dengan yang di harapkan (Anwar, 2000).

Ada beberapa faktor yang bisa mempengaruhi kinerja perawat dalam memberikan asuhan keperawatan yaitu antara lain tingkat pendidikan, pengalaman kerja, beban kerja, pelatihan, tersedianya fasilitas dan kerjasama tim kesehatan lainnya dan dalam acuannya.

Sedangkan hasil penelitian yang dilakukan Zulfakarain Yunus, 2014 terdapat hubungan antara beban kerja dengan pelaksanaan asuhan keperawatan terdapat hubungan antara insentif dengan pelaksanaan asuhan keperawatan antara supervisi, beban kerja, dan insentif dengan pelaksanaan asuhan keperawatan. Berdasarkan hal tersebut diatas peneliti berminat meneliti hal-hal yang Berhubungan Pelaksanaan Asuhan Keperawatan di RS Grandmed Lubuk Pakam tahun 2020".

Karena berdasarkan pengamatan peneliti subyek penelitian memenuhi syarat untuk diteliti serta tersedianya dana dan waktu untuk dilakukan penelitian. Kemudian dari segi etik penelitian tersebut tidak bertentangan dengan etika hukum keperawatan memiliki manfaat bagi peneliti dan penelitian selanjutnya.

\section{METODE}

Dalam penelitian ini peneliti menggunakan penelitian survey analitik dengan pendekatan cross sectional study dimana subjek penelitian dan pengukuran status karakter atau variabel subjek diukur menurut keadaan atau statusnya secara simultan pada satu saat dalam suatu sampel populasi yang representatif atau memberi kesempatan pada peneliti melakukan analisis dari variabel yang diteliti yaitu untuk mengetahui faktor yang berhubungan dengan kinerja perawat dalam pelaksanaan asuhan keperawatan. Penelitian dilaksanakan dengan cara membagikan kuesioner respoden. Penelitian dilaksanakan dengan cara membagikan kuesioner sesuai dengan ketentuan yang telah dibuat oleh peneliti. 


\section{HASIL}

\section{a. Analisis univariat}

Distribusi Responden Pendidikan, Masa

Berdasarkan kerja,Beban kerja,Insentif,Suasana Kerja,Gaya kepemimpinan dan Kinerja Perawat $(n=12)$ Berdasarkan tabel distribusi responden berdasarkan tingkat pendidikan perawat di RS Grandmed Lubuk Pakam.

Menunjukkan bahwa tiap responden memiliki pendidikan yang sama masing-masing $6 \quad(50,0 \%)$ lulusan D3 dan $6(50,0 \%)$ lulusan Ners. berdasarkan Masa kerja perawat di RS Grandmedmenunjukkan bahwa perawat yang masa kerjanya baru sebanyak 7 (58,3\%) dan masa kerja lama sebanyak $5(41,7 \%)$. Distribusi responden berdasarkan beban kerja di RS Grandmed Lubuk Pakam menunjukkan bahwa sebagian besar perawat beban kerjanya tinggi sebanyak 8 (66,7\%). Berdasarkan Tabel distribusi responden berdasarkan insentif menunjukkan bahwa sebagian besar perawat mengangap insentifnya cukup sebanyak $8(67,3 \%)$ dan Kurang sebanyak 4 (33,3\%). Distribusi responden berdasarkan suasana kerja, menunjukkan bahwa perawat sebagian besar perawat menganggap tempat kerjanya kondusif sebanyak 9 (75\%) dan tidak kondusif sebanyak (25\%). Distribusi responden berdasarkan gaya kepemimpinan di RS Grandmed menunjukkan bahwa perawat sebagian besar perawat menganggap gaya kepemimpinan di ruangannya demokratis sebanyak 9 (75\%), Liberal 3 (25\%).
Berdasarkan penelitian yang sudah dilakukan terhadap perawat yang berjumlah 12 orang di RS Grandmed Lubuk Pakam yang telah Variabel yang diteliti

Pendidikan

$\begin{array}{lll}\begin{array}{l}\text { Profesional } \\ (\text { NERS) }\end{array} & 6 & 50 \\ \text { Vokasi } & 6 & 50\end{array}$

Masa Kerja

Beban Kerja

$\begin{array}{lll}\text { Lama } & 5 & 41,7 \\ \text { Baru } & 7 & 58,3 \\ & & \\ \text { Tinggi } & 8 & 66,7 \\ \text { Rendah } & 4 & 33,3\end{array}$

Insentif

$\begin{array}{lll}\text { Cukup } & 8 & 66,7 \\ \text { Kurang } & 4 & 33,3\end{array}$

Suasana Kerja

$\begin{array}{lll}\text { Kondusif } & 9 & 75,0 \\ \text { Tidak } & 3 & 25,0 \\ \text { Kondusif } & \end{array}$

Gaya

Kepemimpinan

Kinerja Perawat

$\begin{array}{lcc}\text { Otoriter } & 0 & 0 \\ \text { Demokratis } & 9 & 75,0 \\ \text { Liberal } & 3 & 25,0\end{array}$

$\begin{array}{lll}\text { Baik } & 7 & 58,3 \\ \text { Kurang } & 5 & 41,7\end{array}$

memenuhi syarat sebagai responden dengan hasil penelitian dengan mengunakan analisis bivariate dengan mengunakan Fisher Exact Test diperoleh data sebagai berikut.

\section{B. Analisis bivariat}




\section{a. Hubungan tingkat pendidikan perawat dengan pelaksanaan asuhan keperawatan}

Berdasarkan tabel diatas dapat dilihat bahwa tingkat pendidikan menunjukkan lebih dari setengah responden yang pendidikannya Ners dalam melakukan asuhan keperawatan baik $(66,7 \%)$, dan responden yang pendidikannya D3 memiliki persentasi yang sama besar antara kinerja baik dan kurang $(50 \%)$. Berdasarkan hasil uji statistik Fisher Exact Test diperoleh nilai $p=1$, hal ini berarti nilai $p>a(0,05)$. Dengan ini menyatakan tidak ada hubungan tingkat pendidikan dengan pelaksanaan asuhan keperawatan di RS Grandmed Lubuk Pakam.

\section{b. Hubungan Masa kerja dengan kinerja perawat dalam pelaksanaan asuhan keperawatan}

Berdasarkan Tabel diatas menunjukkan bahwa pengalaman kerja responden yang masa kerjanya lama sebagian besar dalam melaksanakan asuhan keperawatan baik $(80,0 \%)$, dan responden yang masa kerjanya baru melaksanakan asuhan keperawatan kurang baik $(57,1 \%)$. Berdasarkan hasil uji statistik Chi Square diperoleh nilai $p=0,247$ hal ini berarti nilai $p>$ $a(0,05)$. Hal ini berarti tidak ada hubungan pengalaman kerja perawat dengan kinerja perawat didalam melakukan asuhan keperawatan di Ruang Rawat Inap 3 Depan di RS Grandmed Lubuk Pakam.

\section{c. Hubungan beban kerja perawat dengan kinerja perawat dalam pelaksanaan asuhan keperawatan}

\begin{tabular}{|c|c|c|}
\hline \multicolumn{2}{|c|}{ Variabel } & $\begin{array}{c}P \\
\text { Value }\end{array}$ \\
\hline \multicolumn{3}{|l|}{ Pendidikan } \\
\hline & D3 & 1 \\
\hline & Ners & \\
\hline \multicolumn{3}{|l|}{ Masa Kerja } \\
\hline & Lama & 0,293 \\
\hline & Baru & \\
\hline \multicolumn{3}{|l|}{ Beban Kerja } \\
\hline & Tinggi & 0,010 \\
\hline & Rendah & \\
\hline \multicolumn{3}{|l|}{ Insentif } \\
\hline & Cukup & 0,010 \\
\hline & Kurang & \\
\hline \multicolumn{3}{|c|}{ Suasana Kerja } \\
\hline & Kondusif & 0,045 \\
\hline & Tidak & \\
\hline & Kondusif & \\
\hline \multirow{2}{*}{\multicolumn{3}{|c|}{$\begin{array}{l}\text { Gaya } \\
\text { Kepemimpinan }\end{array}$}} \\
\hline & & \\
\hline & $\begin{array}{l}\text { Demokrasi } \\
\text { Liberal }\end{array}$ & 0,045 \\
\hline
\end{tabular}

menunjukkan bahwa responden yang beban kerjanya tinggi sebagian besar kinerjanya dalam melaksanakan asuhan keperawatan baik $(87,5 \%)$, sedangkan responden yang beban kerjanya rendah lebih kinerjanya dalam melaksanakan asuhan keperawatan kurang baik $(100,0 \% \%)$. Berdasarkan hasil uji statistik Chi Square diperoleh nilai $p=0,010$, hal ini berarti nilai $p<a(0,05)$. Hal ini berarti terdapat hubungan beban kerja perawat dengan kinerja perawat dalam pelaksanaan asuhan keperawatan di RS Grandmed Lubuk Pakam.

\section{d. Hubungan insentif dengan kinerja perawat dalam pelaksanaan asuhan keperawatan}

Berdasarkan tabel insentif menunjukkan bahwa responden yang merasa insentifnya cukup sebagian besar kinerjanya dalam melaksanakan asuhan keperawatan baik $(87,5 \%)$, sedangkan responden yang merasa insentifnya kurang 
memiliki dengan kinerja perawat kurang baik sebanyak (100,0\%). Berdasarkan hasil uji statistik Fisher Exact Test diperoleh nilai $p=0,010$, hal ini berarti nilai $p<a(0,05)$. Hal ini berarti ada hubungan insentif dengan kinerja perawat dalam pelaksanaan asuhan keperawatan di Ruang Rawat Inap 3 Depan di RS Grandmed Lubuk Pakam.

\section{e. Hubungan suasana kerja dengan kinerja perawat dalam pelaksanaan asuhan keperawatan}

Berdasarkan tabel suasana kerja menunjukkan bahwa responden yang merasa suasana kerjanya kondusif sebagian besar kinerjanya dalam melaksanakan asuhan keperawatan baik $(77,8 \%)$, sedangkan responden yang merasa suasana kerjanya kurang kondusif hanya satu saja kinerjanya dalam melaksanakan asuhan keperawatan kurang (100\%). Berdasarkan hasil uji statistik Fisher Exact Test diperoleh nilai $p=0,045$, hal ini berarti nilai $p<a(0,05)$. Hal ini berarti ada hubungan suasana kerja dengan kinerja perawat dalam pelaksanaan asuhan keperawatan di RS Grandmed Lubuk Pakam.

Tenaga perawat tanpa memperhatikan aspek pendidikannya sehingga kecenderungan mereka bekerja berdasarkan standar yang telah ditetapkan di ruangannya masing-masing.

\section{f. Hubungan gaya kepemimpinan dengan kinerja perawat dalam pelaksanaan keperawatan}

Berdasarkan tabel diatas menunjukkan bahwa responden yang menganggap gaya kepemimpinan di ruangannya demokratis sebagian besar kinerjanya dalam melaksanakan asuhan keperawatan baik $(77,8 \%)$, sedangkan responden yang merasa gaya kepemimpinan di ruangannya liberal hanya 3 responden saja kinerjanya dalam melaksanakan asuhan keperawatan kurang baik (100\%). Berdasarkan hasil uji statistik Fisher Exact Test diperoleh nilai $p=0,045$, hal ini berarti nilai $p<a(0,05)$. Hal ini berarti ada hubungan gaya kepemimpinan dengan kinerja perawat dalam pelaksanaan asuhan keperawatan di RS Grandmed Lubuk Pakam Selain itu, di Ruang Rawat Inap 3 Depan di RS Grandmed Lubuk Pakam telah dilakukan pembagian tugas dengan cukup baik antara masing-masing tegana perawat tanpa memperhatikan aspek pendidikannya sehingga kecenderungan mereka bekerja berdasarkan standar yang telah ditetapkan di ruangannya masing-masing.

\section{PEMbahasan}

\subsection{Hubungan tingkat pendidikan perawat dengan kinerja perawat dalam pelaksanaan asuhan keperawatan}

Berdasarkan hasil uji statistik didapatkan tidak ada hubungan tingkat pendidikan perawat dengan pelaksanaan asuhan keperawatan $(p=1)$.

Menurut asumsi penulis,tidak ditemukannya hubungan pendidikan terhadap pelaksanaan asuhan keperawatan dalam penelitian ini kemungkinan disebabkan karena jumlah tenaga perawat yang pendidikannya keperawatan memiliki persentasi yang sama $(50,0 \%)$ sehingga mereka tidak terlalu dapat 
mempengaruhi perawat dengan pendidikan yang lebih rendah.

\subsection{Hubungan masa kerja perawat dengan kinerja perawat dalam pelaksanaan asuhan keperawatan}

Berdasarkan hasil uji statistik didapatkan tidak ada masa kerja perawat dengan pelaksanaan asuhan keperawatan $(p=0,293)$. Menurut asumsi peneliti tidak ditemukan masa kerja perawat dengan kinerja perawat dalam pelaksanaan asuhan keperawatan dalam penelitian ini kemungkinan disebabkan secara umum dalam penelitian ini perawatnya sebagian besar telah memiliki pengalaman kerja minimal satu tahun sehingga mereka telah melakukan proses adaptasi dengan baik dilingkungan kerjanya.

\subsection{Hubungan beban kerja perawat dengan pelaksanaan asuhan keperawatan}

Berdasarkan hasil uji statistik ditemukan adanya hubungan beban kerja perawat dengan pelaksanaan asuhan keperawatan di RS Grandmed Lubuk Pakam $(p=0,010)$ dimana perawat yang beban kerjanya tinggi cenderung memiliki kinerja yang baik dalam pelaksanaan asuhan keperawatan dibandingkan dengan perawat yang beban kerjanya rendah dan faktor yang paling berhubungan dengan kinerja perawat dalam pelaksanaan asuhan keperawatan di RS Grandmed Lubuk Pakam adalah beban kerja.

Hasil penelitian ini sama dengan penelitian yang dilakukan oleh Irwady (2007) yang mendapatkan bahwa beban kerja erat kaitannya dengan produktifitas tenaga kesehatan, dimana 53,2\% waktu yang sangat produktif yang digunakan pelayanan kesehatan langsung (kegiatan langsung) dan sisanya 39,9\% digunakan untuk kegiatan tidak langsung.

Menurut asumsi penulis, Beban kerja perawat dapat mempengaruhi keberhasilan pelaksanaan asuhan keperawatan, hasil penelitian yang didapatkan dari aspek fisik ratarata jumlah perawat di ruangan rawat inap tidak sebanding dengan jumlah pasien yang dirawat, selain itu pekerjaan non keperawatan masih banyak dilakukan oleh perawat. Hal ini sesuai dengan yang dikemukakan Nursalam (2007) bahwa penetapan jumlah perawat berdasarkan kebutuhan klien sangat penting, karena jika jumlah perawat tidak sama dengan jumlah tenaga yang dibutuhkan, tidak ada waktu lagi untuk perawat dalam melakukan tindakan keperawatan yang seharusnya dilakukan sesuai dengan rencana keperawatan, waktu perawat hanya cukup untuk melakukan tindakan kolaborasi dan perawat tidak sempat melakukan tindakan terapi keperawatan, menganalisis tindakan observasi, dan pemberian pendidikan kesehatan.

\subsection{Hubungan insentif dengan pelaksanaan keperawatan \\ asuhan}

Berdasarkan hasil uji statistik didapatkan ada hubungan insentif dengan kinerja perawat dalam pelaksanaan asuhan keperawatan $(p=0,010)$ dimana perawat yang merasa insentifnya cukup cenderung memiliki kinerja yang baik dalam pelaksanaan asuhan keperawatan dibandingkan dengan perawat yang merasa insentifnya kurang. 
Menurut Stoner dan Freeman dikutip dalam Nursalam (2007) keadilan dan penghargaan yang diterima seseorang akan membuat orang tersebut termotivasi dalam pekerjaan sehingga meningkatkan kualitas pekerjaannya. Demikian pula dengan penelitian Wandi (2007) mengungkapkan bahwa beban yang dirasakan lebih berat karena mereka dituntut untuk mampu benar-benar profesional dengan program-program selaku manajer ruangan.

Menurut asumsi penulis, Bagi perawat tentu akan kecewa jika dengan apa yang telah dilakukan namun tidak ada timbal balik sedikitpun dari pihak manejemen rumah sakit walaupun hanya sekedar motivasi atau evaluasi seperti ungkapan salah satu patisipan bahwa reward yang diberikan hanya berupa sakit hati. Dari ungkapan itu ada nada kekecewaan yang dirasakan yang sebenarnya meskipun hanya berupa motivasi atau evaluasi dan bukan reward berupa materi perawat akan merasa lebih dihargai atas kerja kerasnya selama ini pada pasien.

\subsection{Hubungan suasana kerja dengan pelaksanaan asuhan keperawatan}

Berdasarkan hasil uji statistik didapatkan ada $(p=0,045)$ dimana perawat yang suasana kerjanya kondusif cenderung memiliki kinerja yang baik dibandingkan dengan perawat yang suasana krjanya kurang kondusif.

Hasil dari Cox \& Griffith (2006) bahwa keberhasilan seseorang sering tidak terlepas dari bantuan rekanrekan kerjanya, olehnya hubungan yang harmonis perlu tercipta dikalangan pekerja demi pengembangan diri dan organisasi tersebut.
Menurut asumsi penulis, hubungan yang tidak harmonis sering menciptakan kesenjangankesenjangan yang bila dipertahankan dapat mnenjadi beban dalam bekerja. Selain itu, rasa pesimis dan kecemburuan terhadap rekan kerja sering muncul atau timbul, karena keberadaan seorang dalam struktur organisasi tersebut yang merupakan dampak yang terjadi dari kesalahan dalam penyusunan atau pemilihan orang-orang yang duduk dalam suatu struktur keorganisasian, hampir sama dengan dampak yang ditimbulkan pada promosi yang kurang atau berlebihan.

\subsection{Hubungan kepemimpinan}

gaya

Dalam pelaksanaan asuhan $(p=0,045)$ dimana perawat yang menganggap gaya kepemimpinan di ruangannya demokratis cenderung memiliki kinerja yang baik dalam pelaksanaan asuhan keperawatan dibandingkan dengan perawat yang menganggap gaya kepemimpinan di ruangannya otoriter.

Menurut Mayo dikutip dalam Nursalam (2011) menyatakan bahwa pimpinan yang terlalu dominan menyebabkan pegawainya tidak termotivasi dan cenderung pasif, seharusnya seorang pemimpin bisa menempatkan gaya kepemimpinan pada situasinya. Setiabudi (2009) dalam penelitiannya bahwa kepemimpinan yang ada dalam suatu kelompok atau masyarakat tergantung pada situasi yang terdapat pada kelompok/ masyarakat tersebut. Seperti ungkapan dari partisipan yaitu aturan yang ditetapkan semestinya divoting dulu berdasarkan suara terbanyak bukan dari pendapat sepihak, untuk pernyataan ini dalam situasi yang 
sangat menguntungkan atau sangat tidak menguntungkan cenderung gaya kepemimpinannya bersifat otoriter.

\section{KESIMPULAN}

Dari hasil pengolahan data penelitian yang telah dilakukan diperoleh kesimpulan bahwa:

1. Tidak ada hubungan antara pendidikan perawat dengan pelaksanaan asuhan keperawatan di Ruang Rawat Inap 3 Depan RS Grandmed Lubuk Pakam $(p=1)$

2. Tidak ada hubungan antara masa kerja perawat dengan pelaksanaan asuhan keperawatan di Ruang Rawat Inap 3 Depan RS Grandmed Lubuk Pakam $(p=0,293)$

3. Ada hubungan antara beban kerja perawat dengan pelaksanaan asuhan keperawatan di Ruang Rawat Inap 3 Depan RS Grandmed Lubuk Pakam $(p=0,010)$

4. Ada hubungan antara insentif dengan pelaksanaan asuhan keperawatan di Ruang Rawat Inap 3 Depan RS Grandmed Lubuk Pakam $(p=0,010)$.

5. Ada hubungan antara suasana kerja dengan kinerja perawat dalam pelaksanaan asuhan keperawatan di Ruang Rawat Inap 3 Depan RS Grandmed Lubuk Pakam $(p=0,045)$

6. Ada hubungan antara gaya kepemimpinan dengan pelaksanaan asuhan keperawatan di Ruang Rawat Inap 3 Depan RS Grandmed Lubuk Pakam $(p=0,045)$

\section{DAFTAR PUSTAKA}

Asmadi. (2014). Konsep dasar keperawatan. Jakarta: Penerbit Buku Kedokteran EGC.
Dermawan \& Setiawati, 2008, Proses Pembelajaran Dalam Pendidikan Kesehatan, Jakarta, Trans Info Media.

Dewi, Basmala, Gatot dan Wiku, Adisasmito. (2014) Hubungan karakteristik perawat, isi pekerjaan dan lingkungan pekerjaan terhadap kepuasan kerja perawat: Rumah Sakit Muhammadiyah, Bandung 40264, Indonesia, Departemen Administrasi dan Kebijakan Kesehatan, Fakultas Kesehatan Masyarakat: Universitas Indonesia, Depok 16424, Indonesia

Dwidiyanti, (2010), Aplikasi Model Konseptual Keperawatan, Semarang Akper Depkes Semarang

Faizin dan Winarsih (2008) Hubungan Tingkat Pendidikan dan Lama Kerja Perawat Dengan Kinerja Perawat di RSU Pandan Arang Kabupaten Boyolali, Berita IImu Keperawatan ISSN 1979-2697, Vol . 1 No.3, September 2008 : 137- 142

Fathoni, 2010. Abdurrahman. Organisasi \& Manajemen Sumber Daya Manusia. Cetakan Pertama. PT Rineka Cipta : Jakarta

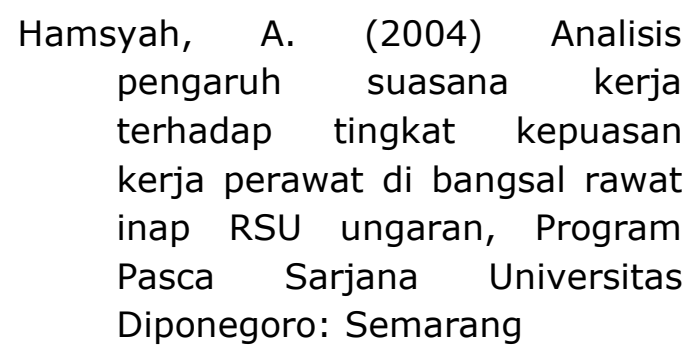

Harsiwi, A.M., (2003). Hubungan kepemimpinan transformasional dan karakteristik personal 
pemimpin. Kinerja: Jornal Bisnis dan Ekonomi Vol 5,(1), Juni 2001. Program 8 Pasca Sarjana Universitas Atmajaya: Yogyakarta

Haryani, F. (2011) Faktor-faktor yang Berhubungan dengan Kinerja Perawat Dalam Kelengkapan Pengisian Dokumen Asuhan Keperawatan Pasien Rawat Inap Kelas III RSUD Kota Semarang, Skripsi, Semarang: Universitas Diponegoro

Natsir \& Joeharno, 2006, "Kinerja Perawat Dalam Melaksanakan Asuhan Keperawatan di Rumah Sakit dan Faktor Yang Mempengaruhi, Skripsi/Tesis, http://www.gooogle.com.id, di akses tanggal 19 Mei 2012.

Sitorus \& Panjaitan. (2011). Manajemen keperawatan:manajemen keperawatan di ruang rawat, ed 1. CV Sagung Seto: Jakarta

Sugiyono (2007) Metode Penelitian Kuantitatif. Bandung: Alphabeta

Tjahjaningrum S, 2004, "Peran Kepala Ruangan Sebagai Supervisor dan Kinerja Perawat Pelaksana Dalam Pelaksanaan Asuhan Keperawatan di Ruang Rawat Inap Medikal Bedah BPRSUD Labuang Baji Makassar", Skripsi tidak diterbitkan, Makassar : Unhas

Wandy, 2007, Faktor-faktor yang Berhubungan dengan Beban Perawat di Unit Rawat Inap RS] Dadi Makassar Tahun 2006, Skripsi tidak diterbitkan, Makassar : Unhas. 